The Sciences in America, Circa 1880

Author(s): Daniel J. Kevles, Jeffrey L. Sturchio and P. Thomas Carroll

Source: Science, New Series, Vol. 209, No. 4452, Centennial Issue (Jul. 4, 1980), pp. 26-32

Published by: American Association for the Advancement of Science

Stable URL: http://www.jstor.org/stable/1684832

Accessed: 13/11/2014 01:43

Your use of the JSTOR archive indicates your acceptance of the Terms \& Conditions of Use, available at

http://www.jstor.org/page/info/about/policies/terms.jsp

JSTOR is a not-for-profit service that helps scholars, researchers, and students discover, use, and build upon a wide range of content in a trusted digital archive. We use information technology and tools to increase productivity and facilitate new forms of scholarship. For more information about JSTOR, please contact support@jstor.org. 


\section{The Sciences in America, Circa 1880}

\author{
Daniel J. Kevles, Jeffrey L. Sturchio, P. Thomas Carroll
}

For many years American science circa 1880 was understood to have been a primitive enterprise, a colonial outpost of European research, an intellectual backwater. The research of the time was written off as merely applied work and, hence, by some mysterious logic, as insignificant. Much of the denigration originated with various contemporary scientists, notably the prominent physicist Henry A. Rowland. In 1883, as a vice

weakness relative to Germany in pure chemistry. The theme was carved in stone in the wake of World War II, a physicist's war, which produced the widespread belief that in the interests of national security vast federal resources had to be invested to overcome the nation's feeble scientific past, this time in physics.

The investments were made, mainly with private and state funds between the

Summary. For many years American science in the late 19th century was regarded as an intellectual backwater. This view derived from the assumption that the health of American science at the time was equivalent to the condition of pure science, especially pure physics. However, a closer look reveals that there was considerable vitality in American scientific research, especially in the earth and life sciences. This vitality is explainable in part by the natural scientific resources of the American continent but also in part by the energy given science from religious impulses, social reformism, and practicality. Furthermore, contrary to recent assumptions, the federal government was a significant patron of American science. The portrait of American science circa 1880 advanced in this article suggests that the nation's scientific enterprise was characterized by pluralism of institutional support and motive and that such pluralism has historically been the normal mode.

president of the American Association for the Advancement of Science, Rowland asked: "What must be done to create a science of physics in this country, rather than to call telegraphs, electric lights, and such conveniences, by the name of science. . . . the cook who invents a new and palatable dish for the table benefits the world to a certain degree; yet we do not dignify him by the name of a chemist"' $(l)$.

Rowland called his celebrated address "A Plea for Pure Science," and since his day a key theme in the disparagement of late 19th-century American science has been its apparent failure to measure up, especially in Rowland's discipline of physics, to some ideal level of pure research $(2,3)$. In the wake of World War I, a chemist's war, the theme of America's past scientific inadequacy received renewed emphasis in the argument that to compete with other countries economically the nation had to overcome its SCIENCE, VOL. 209, 4 JULY 1980 wars and with federal money since 1945 . By now the massive federal expenditures combined with the magnificent achievements of American science since World War II have helped foster an assumption that there was no American science worth speaking about before 1945, let alone as far back as 1880 . But we might note that since Rowland's day the disparagement of the American scientific past has frequently come from the nation's pure scientists; they have often used history to argue for the maintenance or, better, the enlargement of R \& D support. Whatever the merits of their cure for current policy, their historical opinions deserve to be viewed with a certain suspicion.

Of course, just as paranoids may indeed have real enemies, so do complainers often have certain real grievances. In 1880 pure science in the United States, particularly pure physics and chemistry, was not without difficulties.
Yet the weaknesses of pure science ought not to be taken as indicative of the health of American science generally at the time, for as a generation of scholars has begun to show, late 19th-century American science was, taken as a whole, a growing, complex, and by no means unimportant enterprise (4-7).

\section{The American Scientific Community}

In 1880 the American scientific community included some 3300 practitioners, people who to some degree used science in their employment. Some practitioners did research, the majority did not. The number of serious publishing researchers totaled at most about 500 . Affiliated with the practitioners was a group of cultivators; perhaps as many as 2000 people, the cultivators were aficionados, friends, and gadabouts of science, men and women who attended public scientific lectures and read Рориlar Science Monthly. While often knowledgeable, they did not derive their living by practicing science, yet they formed an important social-and economic-link between the practitioners and the larger society. The vast majority of the American scientific community, particularly of the researchers, were white, Anglo-Saxon Protestants. Most were also males. The handful of women scientists of the day taught in women's colleges or worked as assistants to men. About three dozen published research. Few achieved the success and prominence of Maria Mitchell, the astronomer, professor at Vassar College, and fellow of the American Academy of Arts and Sciences $(8)$.

American scientists populated all the major scientific disciplines. In the United States, chemistry was the largest discipline, with just under 2000 practitioners, and physics the smallest, with fewer than 200 (9). Biology, geology, astronomy, and mathematics probably occupied the middle ground. There were no national societies for any of these disciplines except chemistry, and the American Chemical Society was more New York-centered than genuinely national. Except perhaps for the American Naturalist, there were no bona fide national journals for the special disciplines either, even though, like the Journal of the American Chemical Society, various

D. J. Kevles is professor of history in the Division Institute of Technology, Pasadena 91125. J. L. Sturchio and P. T. Carroll are doctoral candidates in the Department of History and Sociology of Science at the University of Pennsylvania, Philadelphia 19104. of Humanities and Social Sciences at the California 


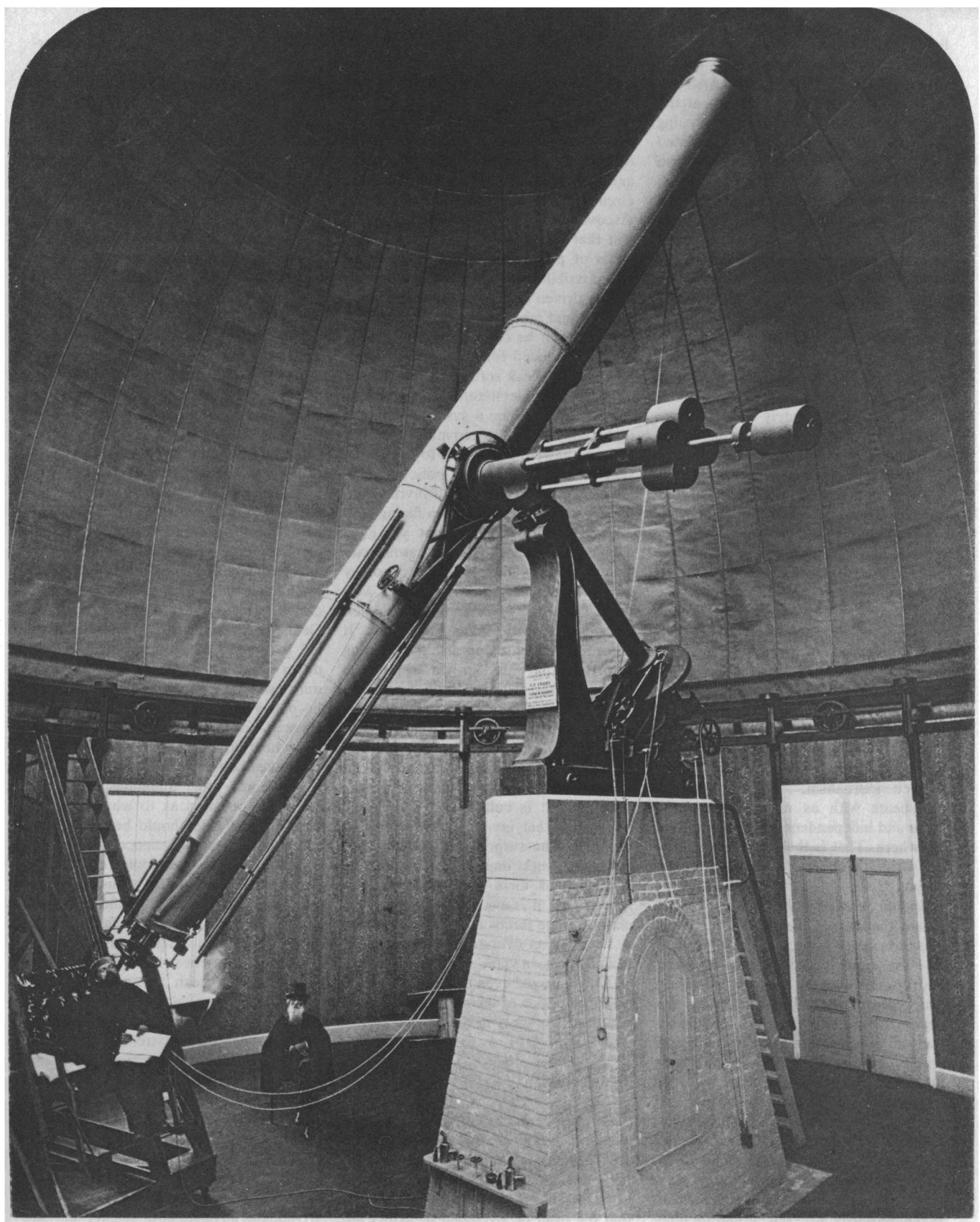

THE GREAT.TELESCOPE.

Made by ALVAN CLARK \&. SONS, Anno Domini 1878.

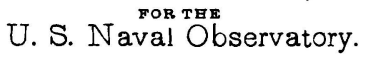

U. S. GRANT. President of the United States.

GEORGE M. ROBESON. Secretary of the Navy. 


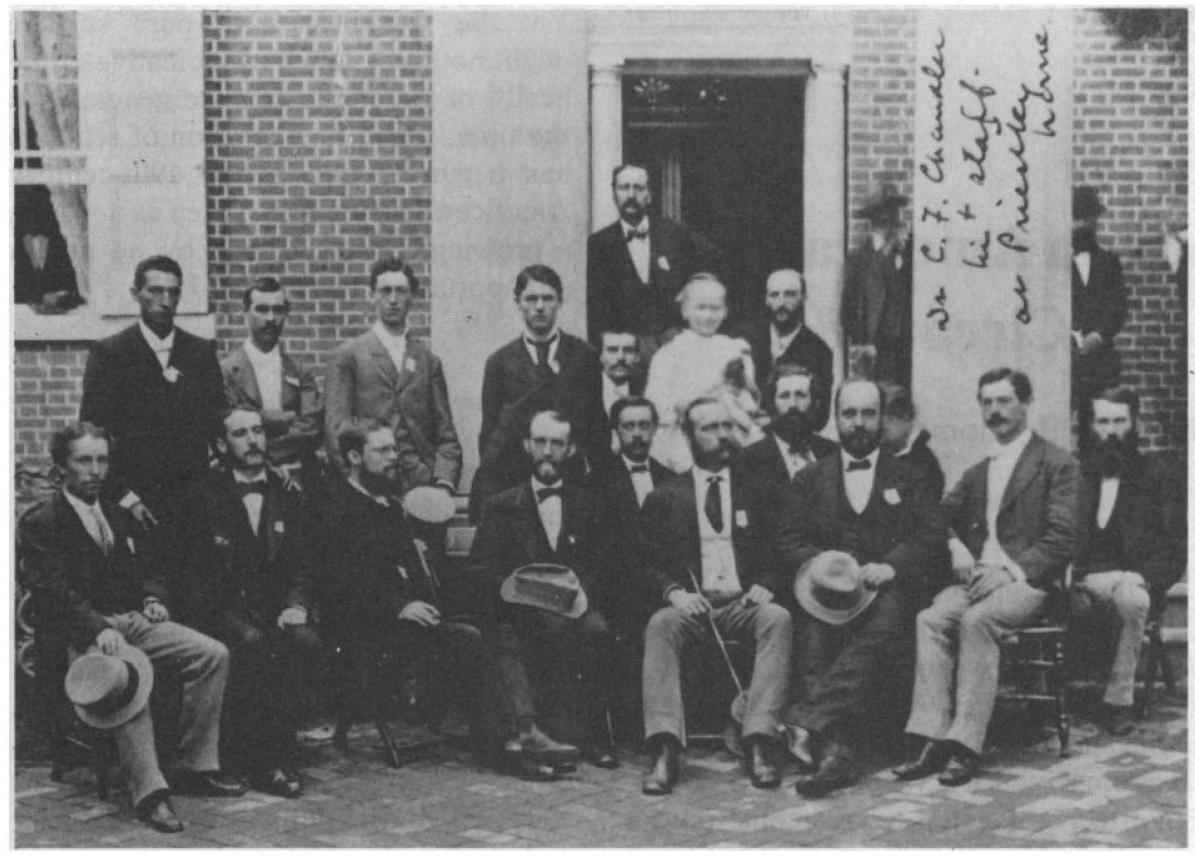

Charles F. Chandler (1836-1925) and his coterie from the Columbia School of Mines at the centennial celebration of Joseph Priestley's discovery of oxygen, Northumberland, Pennsylvania, 1 August 1874. Discussions that afternoon launched a movement that culminated in the establishment of the American Chemical Society in New York City on 6 April 1876. Seated (from left to right) are A. H. lliot, C. S. Allen, C. G. Adams, C. A. Joy, E. J. Hallock, Chandler, E. Waller, H. C. Bolton, J. A. Church, and (probably) C. E. Pellew. Standing (from left to right) are C. A. Sniffin, W. H. S. Thorburn, W. M. Iles, A. Macy, M. S. Thompson, L. H. Laudy, M. W. Chandler, and S. A. Goldschmidt. [Photo courtesy of the Edgar Fahs Smith Memorial Collection, Van Pelt Library, University of Pennsylvania]

other publications did sport national names. Americans published in the multidisciplinary American Journal of Science, the leading organ of research in the United States. Still, they often broadcast their very best research first in the scientific journals of Europe.

Much of American scientific activity was characterized by localism. Astronomers published in observatory bulletins; members of other disciplines often aired their work in the proceedings of local scientific academies (which is why it should not be surprising that $J$. Willard Gibbs published his classic $p$ pers on the equilibrium of heterogeneous substances in the Proceedings of the Connecticut Academy of Sciences). The study of natural history had long given vitality to the local scientific societies. In 1880 they continued to provide a forum where cultivators could conjoin with college professors to discuss specimens of local flora, fauna, geological formations, and mineral resources. In 1883 Samuel $H$. Scudder, the editor of Science, could still urge eager amateurs to collect specimens for discussion by experts at local society meetings. "Every field," Scudder declared, "affords problems in geology, botany, entomology, etc., the solution of which is within the limits of the simplest research ..." (10).

Around 1880 , local scientific societies institutionally expressed the cultural union, though it was declining, between professional practitioners of science and its lay cultivators. The very local American Chemical Society of the day tied together in a nominal commitment to public service professional chemists of New York City with public officials and members of the urban commercial establishment. Exemplifying these bonds, the dominant figure in the society was Charles Frederick Chandler, head of the Chemical Department at the Columbia School of Mines and simultaneously a faculty member at the College of Physicians and Surgeons as well as the College of Pharmacy, president of the Metropolitan Board of Health, consultant to manufacturers, and a member of both the University Club and the Century Association.

But local loyalties like Chandler's distressed chemists in Philadelphia, Cambridge, Massachusetts, and Washington, D.C., and they withdrew from the American Chemical Society in such numbers as to render it virtually moribund by the end of the 1880's. Serious researchers everywhere were coming to emphasize the advancement of their disciplines over any response to local public or industria needs. Mainly academic or government scientists, the serious researchers were also growing ever more committed to professionalism and to the exclusion of amateurs. They emphatically agreed with Henry Rowland, who contemptuously wrote off local scientific societies as merely "dignified by high-sounding names," each with "its local celebrity, to whom the privilege of describing some crab with an extra claw ... is inestimable." The professional researchers increasingly felt the impulse to specialize, and to form specialized societies. In the 1890's the Washington, Philadelphia, and Cambridge chemists would take over the American Chemical Society and shape it to their own national ambitions. The professionals were leaving the local scientific societies to the cultivators and to public education through lectures, exhibits, and museums (11). The professionals restricted control of the American Association for the Advancement of Science to fellows who were accomplished in research. And in their scientific fields they pursued the major research subjects of western European science.

\section{Activities and Opportunities in Research}

For the most part, American biology meant natural history, particularly as it bore upon Darwin's theory of evolution. The emerging field of laboratory physiology was less evident in the United States, though H. Newell Martin had established a beachhead for the subject at the recently founded Johns Hopkins University. For the most part, too, American mathematics was more a servant than a queen of the sciences; as in Europe it was mainly concerned with astronomical problems, but unlike Europeans, American mathematicians were little involved in the new branches of analysis. Like Europeans, American physicists focused on heat, light, electricity, and magnetism. Like Europeans, too, American chemists explored atomic weights, chemical analysis, and the identification of the elements. Few Americans dealt with physical chemistry, but so did few Europeans. In organic chemistry, Europeans were indisputably in the vanguard. Like European astronomers, Americans engaged in the complementary activities of observations and computations concerning the positions of planets, moons, and stars, while some helped usher in the new astrophysics. And like European geologists, Americans contributed to classical evolutionary geology, to the vigorously disputed question of the age of the earth, and to the newly developing area of geophysics. 
In most fields of research there were Americans of considerable distinction. In 1880, the American physics community included $\mathbf{J}$. Willard Gibbs, a genius for any age, already feted by Maxwell for his work on chemical thermodynamics; Albert A. Michelson, who commanded an international reputation for his measurement of the speed of light; and of course Henry Rowland, who in 1883 would astonish students of spectroscopy with his diffraction grating. In chemistry, Josiah Parsons Cooke had solidly established the atomic weight of antimony and Wolcott Gibbs had pioneered electrochemical analysis. If Americans were slow to enter organic chemistry, Ira Remsen, a codiscoverer of saccharin, was spearheading the development of that field in the United States both in his own research and by editing the American Chemical Journal. In evolutionary biology, Othniel C. Marsh's unearthing of ancient horses and of birds with teeth was pronounced by Darwin to be the best confirmation of his evolutionary theory.

In 1877 the American Asaph Hall excited the world of astronomy with his discovery of the moons of Mars. Henry M. Draper and Lewis M. Rutherfurd of New York helped introduce gelatinous dry-plate stellar photography; some of their photographs were acclaimed by Europeans as better than any obtained on their side of the Atlantic. By 1880 Charles A. Young and Edward C. Pickering had ably contributed to the study of solar and stellar spectra, and Samuel Pierpont Langley had advantageously applied his bolometer to studies of sunspots and the sun's surface temperature. In geology Clarence Dutton of the United States Geological Survey commanded international attention with his concept of isostasy, which aimed at an explanation of mountain building, a prime topic of debate in the discipline at the time. In mathematics, G. W. Hill hit upon the idea of infinite determinants in the course of analyzing the relative motions of the earth, sun, and moon.

On the whole, with the salient exception of J. Willard Gibbs, American science tended not to be theoretical. Furthermore, its quality, varying from discipline to discipline, was uneven. Efforts in astronomy, evolutionary biology, and the earth sciences were often outstanding. In 1880 no fewer than 31 Americans were listed as foreign members of the Geological Society of London. In physics and chemistry the United States was on the whole much weaker, though quite respectable in branches of those disciplines related to the earth sciences.
Europeans respected the work in mineral chemistry of F. A. Genth, J. Lawrence Smith, T. Sterry Hunt, W. F. Hillebrand, and F. W. Clarke. In 1880 the physicist Carl Barus joined the United States Geological Survey to aid the study of evolution through the laboratory analysis of rocks and minerals at high temperatures and pressures, and in due course Barus earned an international reputation in pyrometry.

In whatever areas Americans did well, their research was marked by strength in observation, experiment, measurement, and the development or exploitation of new instruments. So it was with positional astronomy, stellar photometry, and spectroscopy; with measurements of the speed of light or the caloric equivalent of work; with the analyses of chemical compounds, the determination of atomic weights, the identification of elements; with the gathering of paleontological specimens or the recording of new geological formations. What made for this style in American science was partly the absence of intensive and systematic training in theory, especially of a mathematical type; partly scientific tradition, the stress on observation and experiment handed down from teacher to student and exemplified in American scientific publications. But what also made for it were the types of research opportunities that readily presented themselves to American researchers.

Geologists saw spread before them an entire continent of marvelous resources, from the Palisades, the Catskills, and the Delaware Water Gap in the East, out to the rolling Mississippi Valley in the Midwest, and on to the thousands of square miles of high plains and majestic mountains, the Great Salt Lake, Death Valley, and the Grand Canyon in the West. From Point Sublime in the Grand Canyon geologists could view their subject with a perspective unparalleled until the introduction of the airplane and the space probe. In humid regions, eroded formations were covered by soil; in the starkly arid west numerous instructive features remained unobscured. In fact, American geological formations drew investigators from the world over. Archibald Geikie, after 1882 head of the Geological Survey of the United Kingdom, recognized that the American advantage in the discipline sprang "from the marvellous geological riches of the American continent itself. In minerals and rocks, in stratigraphical fulness, in palaeontological profusion, in physiographical illustrations, the United States have not only no need to borrow from Europe, but in many important respects can produce

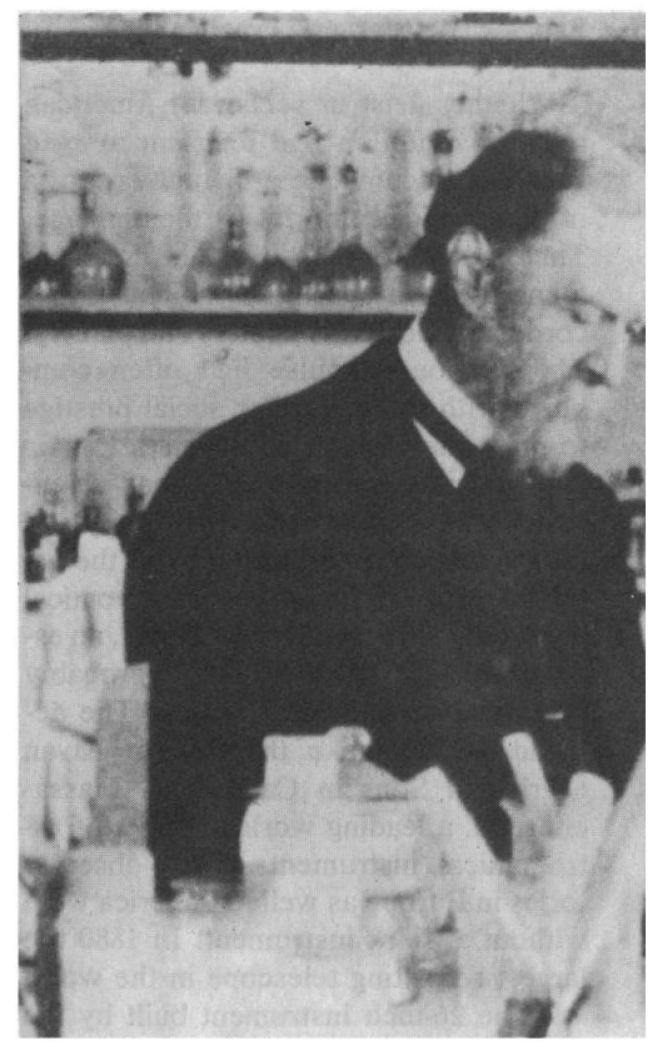

Wolcott Gibbs in his laboratory circa 1880 With his students at the Lawrence Scientific School of Harvard University, Gibbs (18221908) added electrogravimetric methods to the chemist's analytical repertoire during the 1860 's and 1870's. His researches on cobaltammines and complex inorganic acids, often published in German journals as well as in the American Journal of Science and the American Chemical Journal, were widely known in European chemical circles. [Photo courtesy of the Edgar Fahs Smith Memorial Collection, Van Pelt Library, University of Pennsylvania]

examples and materials such as cannot be equalled on this side of the Atlantic. Had the study of the earth begun in the New World instead of the Old, geology would unquestionably have made a more rapid advance ..." (12).

Similarly, the continent supplied a treasure house for fossil remains and a vast zoo, aquarium, and aviary for the study of variegated life forms. Situated at a more southerly latitude than European astronomers, Americans could better study the heavens of southern declination. Nevertheless, it would be a mis take to attribute American scientific vitality entirely to American geographical circumstance. For to observe that the rich resources established possibilities and opportunities does not reveal why those resources were turned to scientific advantage. For that explanation, one must look in areas often discounted in connection with science-religion, social status and reform, and a penchant for practicality. 


\section{Religion, Reform, and Practicality}

Whether deist or sectarian, American religious tradition had long encouraged of the Creator's imprint on the universe. Thus, amateurs had long laid flora and fauna away in specimen cabinets or recorded the positions of stars and planets. The religious impulse had often combined with the desire for social prestige to point the way for new wealth to gain respectability by endowing good scientific works. Thus, both philanthropy and public subscription had fostered the establishment of numerous astronomical observatories in the United States, an estimated 144 of them by 1882 , probably more than in any other nation. The demand helped make the firm of Alvan Clark and Sons in Cambridge, Massachusetts, a leading world supplier of astronomical instruments. Few observatories in Europe as well as America were without a Clark instrument. In 1880 the largest refracting telescope in the world was the 26-inch instrument built by the Clark firm for the United States Naval Observatory. In 1887 the title was transferred to the 36-inch refractor, also built by Clark, for the new Lick Observatory people to accumulate a factual variorum

in California, which had been endowed in typical philanthropic fashion by James Lick upon his death in 1874 (13)

Religious drives had also helped install solid scientific courses in the pre-Civil War American college, and they had joined with the philanthropic impulse to establish numerous natural history museums both on and off the campuses. In the post-Civil War era, social reformism boosted the academic role of the sciences, stimulated the development of laboratory instruction and graduate training, and catalyzed the transformation of the American college into the American university. The new universities were at least nominally committed to research. The newly founded Johns Hopkins University was genuinely committed to it, with a faculty that in $\mathbf{1 8 8 0}$ included Ira Remsen, Henry Rowland, and James J. Sylvester, and with a president who offered Josiah Willard Gibbs a paid professorship just a few years later (14).

On the practical side, the model of the German dye industry and its academic alliances had not taken hold in the United States. It was not only that America lacked the resources of Germany with regard to organic chemistry. It

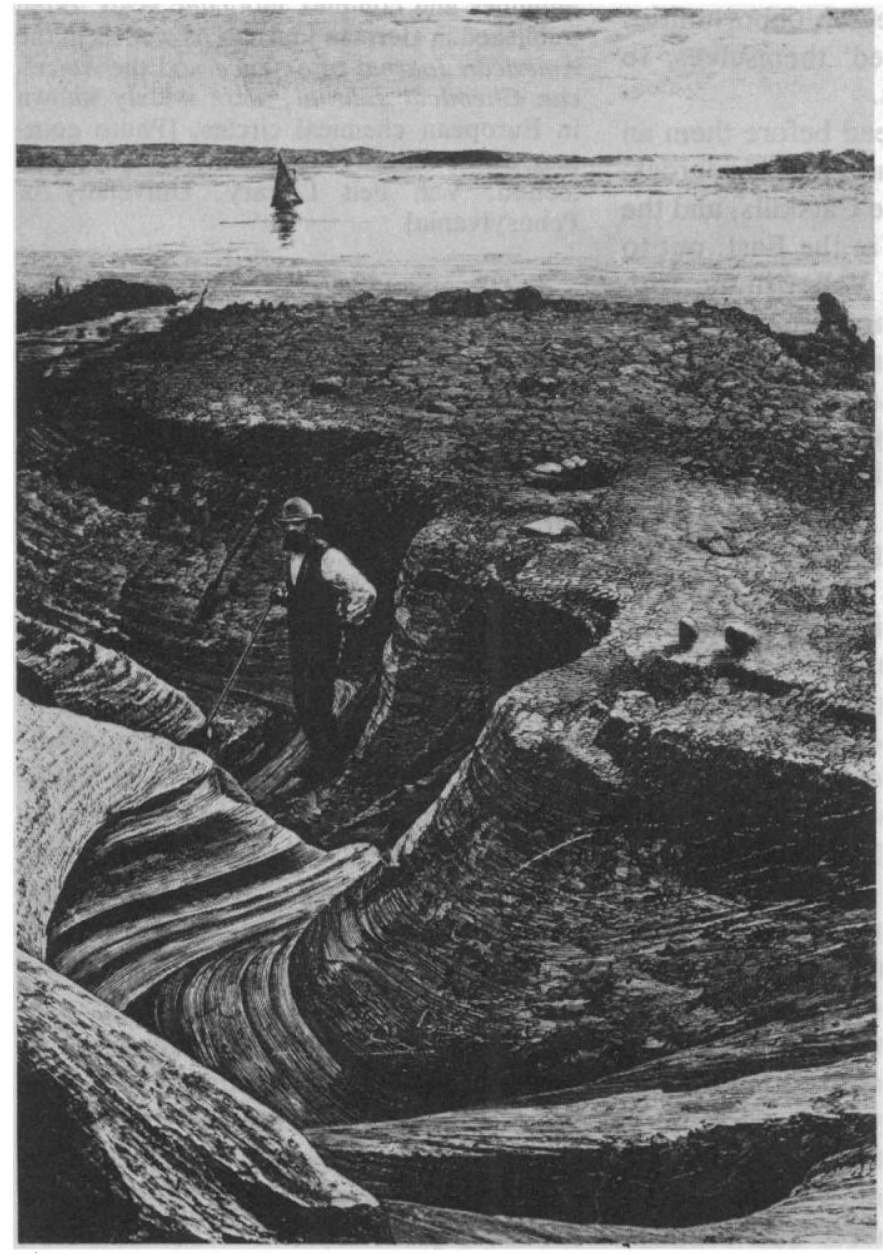

Powell authorized Survey investigations in topography. Here a surveyor is exploring glacial grooving, Kelley's Island, Lake Erie. [Photo courtesy of U.S. Department of the Interior, Geological Survey] was also that, in contrast to Höchst or Badische Anilin und Soda Fabrik, U.S. chemical firms were probably not yet appropriately oriented to their markets to use surplus capital for support of longterm research and development. But even if American industry had not yet set chemists to the systematic development of new products and processes, practical matters certainly stimulated a considerable part of the American chemical enterprise. Some 90 percent of American chemists were employed outside the academic world, and the vast majority worked in industry and commerce, some as chemical entrepreneurs, most as bench analysts. In-house control laboratories were established by various firms, including the Pennsylvania Railroad, which in 1875 hired Charles B. Dudley to test materials, study the causes of boiler scale, and investigate the relations between the chemical composition and physical properties of steel. Dudley's laboratory was so successful that seven other major railroads had followed suit by the 1880 's, and in 1887 chemists from these companies formed the American Association of Railway Chemists to standardize analytical methods and to share information (15).

Firms that did not establish their own testing laboratories could turn to consultants, either independent or academic. Consulting chemists marketed their professional expertise for analyses of ores and chemical products, advice on industrial processes, and testimony in patent litigation. Often, the successful consulting chemist studied in Germany, published in professional journals, then opened an independent laboratory in a center of chemical manufacturing. James Booth typically had done just that in 1836 after returning from study under Wöhler and Magnus. During the next few decades, Booth analyzed iron ores and coal samples from the Pennsylvania anthracite regions, investigated methods of sugar refining for local manufacturers, and from 1849 to 1887 served as assayer for the United States Mint in Philadelphia. Booth also taught analytical chemistry at his laboratory, and many of his students became industrial consultants (16).

No less important as consultants were academics. At the Columbia School of Mines, Charles F. Chandler and his associates spent a few hours each day on commercial analyses, which enabled Chandler to enjoy an income at least three times higher than the best academic salaries of the period. Academic geologists consulted to mining firms, and so did academic physicists to 
firms in the electrical industry. In 1879 Thomas A. Edison had successfully demonstrated his carbon filament lamp system, and most physicists of the day did not exclude electric lights and telephones from the proper purview of their discipline. If Rowland proposed to do so in his celebrated plea for pure science, it was very likely out of pique at Edison himself, who was understood to be at once an entrepreneur, inventor, and man of science, and, who, unlike Rowland, was a public hero (17).

\section{Science and Government}

Many practical scientists of the day were animated not only by economic self-interest but also by a commitment to public service. Science "ennobles and purifies the mind," President Charles William Eliot of Harvard had declared. (18). Scientists frequently liked to consider themselves disinterested as well as expert, moral as well as knowledgeable, and particularly well qualified to contribute to the framing of sound public policy where technical issues were in question. Activist scientists sought a public role for themselves in the late 19th century, when the national government was fostering industrial growth, railroad construction, and the development of western lands, and when state and local governments were enmeshed in matters of public health, water supply, and transportation. Government officials responded to the claims of the activists. As a result, practical concerns made government at all levels a major home of science.

Chemists worked in state and local assay offices and public health agencies. As president of the New York Board of Health from 1873 to 1883 , Charles F. Chandler investigated the causes of kerosene explosions, milk adulteration, water pollution, and gasworks nuisances. (19). By the late 1880's many chemists and biologists were employed in state agricultural experiment stations. Practical interests had of course made for the establishment of the land-grant colleges; despite their commitment to applied subjects, they nevertheless provided, like the experiment stations and public health agencies, positions and laboratories exploitable for basic science. At the federal level, a utilitarian interest in weather prediction made the United States Weather Service a locus for basic research in meteorology, and a practical concern for mapping contributed to the distinguished geodetic research of the
United States Coast and Geodetic Survey.

A practical demand for information essential to navigation and chronometry energized the government's ongoing commitment to the United States Naval Observatory, one of the leading centers of positional astronomy in the world. In the spirit of the day, Samuel Pierpont Langley, even before he came to the Smithsonian Institution and inaugurated his experiments with heavier-than-air flight, perceived practical possibilities in the pursuit of the new solar physics. "It is simply . . . a question of time," Langley wrote in 1879, "when . . . [solar] engines may become an economical as well as a mechanical success, and in a larger sense it is still only a question of time when the rapidly consuming coal-beds of Great Britain yield their last, and her manufacturing empire is transferred to countries which have not exhausted their supply. But these will exhaust their own in turn; the stock, though great, is finite and not renewable; and we must look, for the only power we know which can replace coal, to those regions of the earth now desolated by solar heat, and to which future empire may probably tend" (20).

The states had long fostered geological surveys, and now no scientific discipline attracted more federal attention, for its glamour as well as practical importance, than geology. Geologists had not played any part in the initial discoveries of gold in California and Colorado or of silver in Nevada, but in the decades following these strikes they had begun to analyze and codify the types of geological structures associated with rich mineral lodes. In 1870 James D. Hague, a member of the United States Geological Exploration of the Fortieth Parallel, had written with Clarence King the monumental Mining Industry, a study of the fabled Comstock Lode and the first comprehensive account of its kind. When King became the first director of the United States Geological Survey in 1879, he opened a district office in Denver, with Samuel F. Emmons, a Harvard-trained geologist, in charge; 6 years later Emmons published his Geology and Mining Industry of Leadville, Colorado, a massive general and descriptive geology of the surrounding mountain range that stimulated miners in other regions to petition the Survey for similar studies of their own sites (21).

For all King's achievement, his successor John Wesley Powell was still more adept at exploiting the nation's commitment to practical science. Powell aimed to use geological research as a tool to recast the West into a region of economic opportunity, and he made the Survey into a wide-ranging inquiry concerning the physical evolution and economic possibilities of the land. Politically astute, he distributed the Survey's attractively, sometimes lavishly, illustrated publications around the capital.

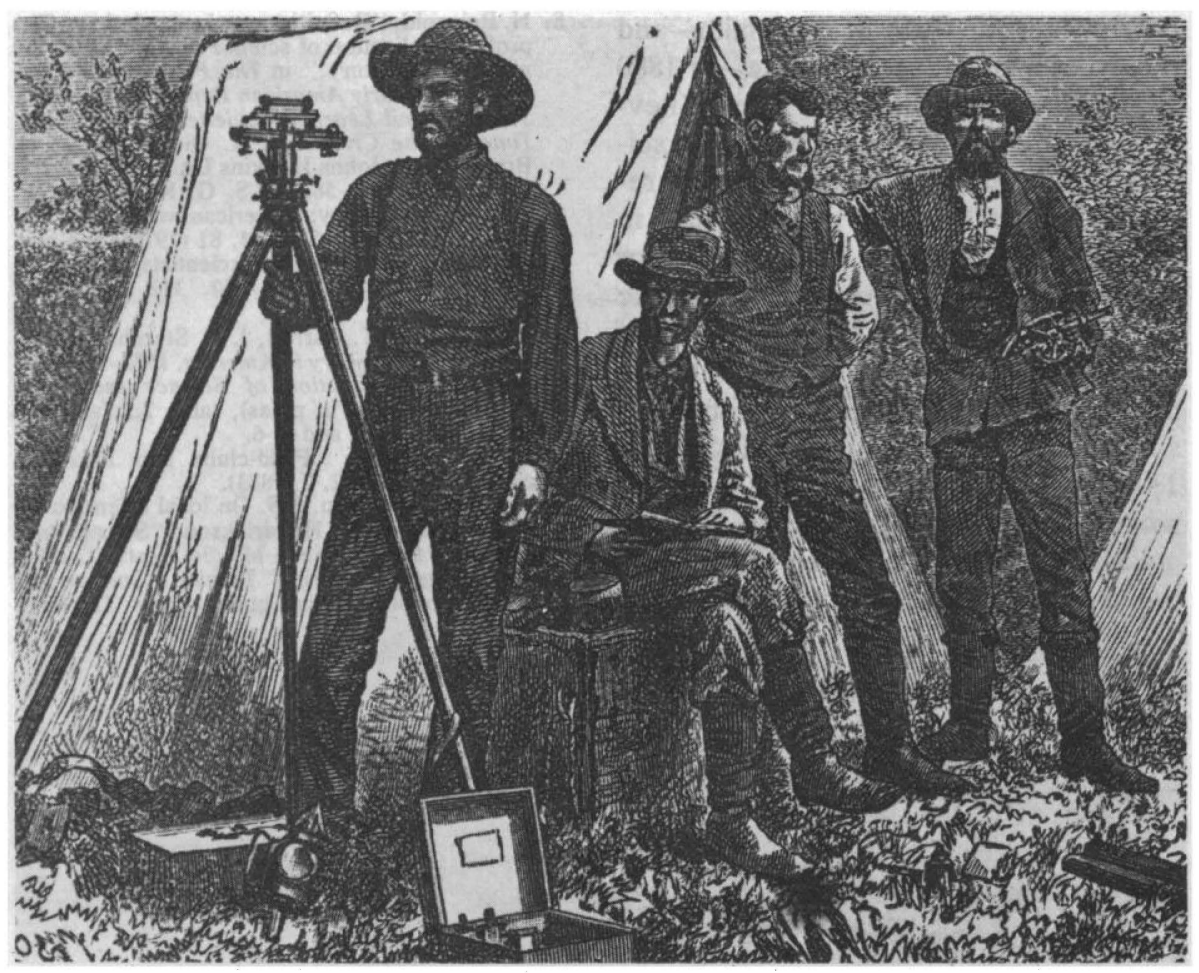

Western scene from early U.S. Geological Survey report-surveyors on an early Survey expedition. [Photo courtesy of U.S. Department of the Interior, Geological Survey] 
Between 1881 and 1884 , when the federal budget totaled less than $\$ 1$ billion, the Survey's annual budget jumped to almost $\$ 500,000$, a fivefold increase. Powell employed topographers, geologists, and paleontologists; he gave work to university consultants, including Othniel C. Marsh. Through the consultantships and field expeditions the Survey provided important research opportunities for many American geologists, and its access to the Government Printing Office endowed the geology profession with the equivalent of its own major research journal.

Thus in 1880, the federal government, with its Weather Service, Naval Observatory, Coast and Geodetic Survey, and various other offices and departments, was the home of much of American science. The Government Printing Office, which since 1870 had issued hundreds of memoirs for the scientific bureaus, was the nation's principal publisher of research. Relative to population, more scientists were working in the nation's capital than in any other city, including Cambridge, Massachusetts. In a short while Congressman Hilary Abner Herbert from Alabama would charge that the United States government was extravagantly investing more annually in scientific research than all the nations of western Europe combined (22).

\section{Pluralism}

Whatever the truth of that claim-and it may well have been accurate-in 1880 government, both state and federal, nevertheless did not dominate American science. It funded neither academic research nor, for the most part, research in physics and chemistry. No single aim or patron governed the American scientific enterprise. It was marked by pluralism of motive-religion, social respectability or reform, as well as practicality - and by a similar pluralism of institutional identity. This pluralism has prevailed through most of American scientific history; measured against the sweep of the past, the conditions since 1945 have tended to be anomalous. Perhaps we may suggest that, while the federal role will continue to be substantial, it should not blind us to the possibilities of a renewed pluralism in the future. Certainly it should not obscure the respect due the pluralist situation of 1880. At that time American science may have been weak in certain branches; it may have been wanting in theory. Yet despite a lack of massive government support or an overarching commitment to pure science, pluralism made for first-rank positions in the earth sciences, natural history, and astronomy, and it was already fostering rapid improvement in other important disciplines.

\section{References and Notes}

1. H. A. Rowland, “A plea for pure science," Science 2, 242 (1883)

2. For the classic statement of this argument see $\mathbf{R}$ H. Shryock, "American indifference to basic science during the nineteenth century," Arch. Int. Hist. Sci. 28, 50 (1948). An alternative perspective is provided by $\mathbf{N}$. Reingold, "America indifference to basic research: A reappraisal,' in Daniels (3), pp. 38-62

3. G. H. Daniels, Ed., Nineteenth-Century American Science: A Reappraisal (Northwester Univ. Press, Evanston, Ill., 1972)

4. For introductions to this scholarship, see $(3,5-$ 7).

5. D. J. Kevles, The Physicists: The History of a Scientific Community in Modern Americ (Knopf, New York, 1978).

6. A. Oleson and J. Voss, Eds., Organization of Knowledge in Modern America, 1860-192 Johns Hopkins Univ. Press, Baltimore, 1979).

7. N. Reingold, Ed., Science in America since 1820 (Science History Publications, New York, 1976); The Sciences in the American Context: New Perspectives (Smithsonian Institution Press, Washington, D.C., 1979); Science in Nineteenth-Century America: A Documentary History (Hill and Wang, New York, 1964); C. E. Rosenberg, No Other Gods: On Science and American Social Thought (Johns Hopkins Univ. Press, Baltimore, 1976).

8. N. Reingold, "Definitions and speculations: The professionalization of science in America in the professionalization of science in America in the
nineteenth century," in The Pursuit of Knowl-
edge in the Early American Republic: American Scie in the Early American Republic: American Times to the Civil War A. Oleson and S. C. Times to the Civil War, A. Oleson and S. C. more, 1976), pp. 58, 63; S. G. Kohlstedt, "I more, 1976), pp. 58, 63; S. G. Kohlstedt, "In from the periphery: American women in science, 1830-1880," Signs 4, 81 (1978). See also before 1920," Am. Sci. 62, 312 (May-June 1974).

9. R. F. Bud, P. T. Carroll, J. L. Sturchio, A. W. Thackray, Chemistry in America, 1876-1976: An istorical Application of Science Indicators Reidel, Boston, in press), table 2.2; see also Kevles (5), p. 37 and n. 6.

10. S. H. ,Scudder, "Field-clubs and local societies," Science 2, 2 (1883).

11. See Rowland (1), p. 249. On local scientific societies, see W. B. Hendrickson, "Science and 326 (September $19 \rightarrow$ T. Bender, "Science and the culture of American communities: The nine- teenth century," Hist. Educ. Q. 16, 63 (spring 1976); S. G. Kohlstedt, "From learned society to public museum: The Boston Society of Natu406; D. Sloan, "Science in New York City, 1867-1907,"'Isis 71, 35 (March 1980). On the American Chemical Society, see C. A. Browne and M. E. Weeks, A History of the American Chemical Society: Seventy-Five Eventful Years (American Chemical Society, Washington, D.C., 1952); E. H. Beardsley, The Rise of the American Chemistry Profession, 1850-1900 (Univ. of Florida Press, Gainesville, 1964), pp.

12. A. Geikie, The Founders of Geology (Macmillan, New York, 1897), pp. vii-viii; quoted in Science 6, 630 (1897). See also "Geikie's geological sketches," ibid. 1, 280 (January-June 1883)

13. A. M. Clerke, A Popular History of Astronomy during the Nineteenth Century (Adam and Charles Black, London, ed. 4, 1902), p. 7. See also D. B. Herrmann, "An exponential law for the establishment of observatories in the nineteenth century,"' J. Hist. Astron. 4, 57 (1973); D. J. Warner, Alvan Clark \& Sons: Artists in Optics (U.S. National Museum Bulletin 274, Smithsonian Institution Press, Washington, D.C., 1968) H. S. Miller, Dollars for Research: Science and Its Patrons in Nineteenth-Century America (Univ. of Washington Press, Seattle, 1970), pp. 24-47, 98-118.

14. H. Hovenkamp, Science and Religion in America, 1800-1860 (Univ. of Pennsylvania Press, Philadelphia, 1978); S. M. Guralnick, Science and the Ante-Bellum American College, Memoirs of the American Philosophical Society (American Philosophical Society, Philadelphia, 1975), vol. 109.

15. J. J. Beer, The Emergence of the German Dye Industry (Illinois Studies in the Social Sciences, Univ. of Illinois Press, Urbana, 1959), vol. 44, pp. 57-93; Chemistry in America (9), tables 2.2 5.16 and 5.17; C. B. Dudley, "The dignity of analytical work," J. Am. Chem. Soc. 20, 81 (1898); Memorial Volume Commemorative of the Life and Life-Work of Charles Benjamin Dudley (American Society for Testing Materials, Philadelphia, 1911); "American Association for Railway Chemists-1887," no publisher, no date, pamphlet in Charles F. Chandler Papers, Clubs and Societies, Box 1, Butler Library, Columbia University.

16. E. F. Smith, "James Curtis Booth, chemist, 1810-1888," J. Chem. Ed. 20, 315 (1943).

17. D. A. Hounshell, "Edison and the pure science ideal in 19th-century America," Science 207, 612 (1980)

18. Quoted in Kevles (5), p. 24.

19. M. T. Bogert, "Biographical memoir of Charles F. Chandler, 1836-1925," Biogr. Mem. Nat. Acad. Sci. 14, 125 (1931); R. L. Larson, "Charles Frederick Chandler: His life and work," thesis, Columbia University (1950); J. Duffy, A History of Public Health in New York York, 1974).

20. S. P. Langley, "The recent progress of solar physics," Pop. Sci. Mon. 16, 9 (November 1879)

21. See W. H. Goetzmann, Exploration and Empire: The Explorer and the Scientist in the Winning of the American West (Knopf, New York, 1966), chaps. 9-15; T. G. Manning, Government in Science: The U.S. Geological Survey, 18671894 (Univ. of Kentucky Press, Lexington, 1894 (Univ. of Kentucky Press, Lexington, West, 1848-1880 (Holt, Rinehart and Winston, New York, 1963).

22. See Kevles (5), pp. 50, 63, 65, A. Hunter Dupree, Science in the Federal Government: $A$ (1957). vard Univ. Press, Cambridge, Mass., 1957),

23. We thank Steven Shapin for his comments. 